FITRAH Jurnal Kajian Ilmu-ilmu Keislaman

Vol. 03 No. 2 Desember 2017

e-ISSN : 2460-2345, p-ISSN: 2442-6997

Web: jurnal.iain-padangsidimpuan.ac.id/index.php/F

\title{
BELAJAR DAN PEMBELAJARAN
}

\author{
Aprida Pane \\ Muhammad Darwis Dasopang \\ IAIN Padangsidimpuan \\ Afridapane.yes@gmail.com; dasopang.yes@gmail.com
}

\begin{abstract}
Abstrack
This study aims to discuss the learning and intruction which is an activity conducted by teachers and students. Learning is the process of changing a behavior and knowledge. Learning process becomes one system in intruction. The intruction system consists of several components that interact with each other, that is: teachers, students, learning objectives, materials, media, methods, and evaluation. The intruction can not be done well without any interaction between the learning components, then all components of learning must cooperate to make a efficient learning.
\end{abstract}

Keywords: Learning, Teaching, Learning Component

\begin{abstract}
Abstrak
Kajian ini bertujuan untuk membahas hakikat belajar dan pembelajaran yang merupakan suatu kegiatan yang dilakukan oleh guru dan siswa. Belajar adalah proses perubahan tingkah laku dan ilmu pengetahuan. Proses belajar menjadi satu sistem dalam pembelajaran. Adapun sistem pembelajaran terdiri dari beberapa komponen yang saling berinteraksi satu sama lain, yaitu: guru, siswa, tujuan, materi, media, metode, dan evaluasi. Pembelajaran tidak akan dapat terlaksana dengan baik tanpa adanya interaksi antara komponen pembelajaran, maka diantara jenis komponen pembelajaran tersebut haruslah saling bekerja sama sehingga tercipta pembelajaran yang efisien.
\end{abstract}

Kata Kunci: Belajar, Pembelajaran, Komponen Pembelajaran.

\section{PENDAHULUAN}

Belajar dan pembelajaran adalah dua hal yang saling berhubungan erat dan tidak dapat dipisahkan dalam kegiatan edukatif. Belajar dan pembelajaran dikatakan sebuah bentuk edukasi yang menjadikan adanya suatu interaksi antara guru dengan siswa. Kegiatan belajar mengajar yang dilakukan dalam hal ini diarahkan untuk mencapai tujuan tertentu yang telah dirumuskan sebelum pengajaran dilakukan. Guru secara sadar merencanakan kegiatan pengajarannya 
FITRAH Jurnal Kajian Ilmu-ilmu Keislaman

Vol. 03 No. 2 Desember 2017

secara sistematis dengan memanfaatkan segala sesuatunya untuk kepentingan dalam pengajaran.

Belajar dimaknai sebagai proses perubahan perilaku sebagai hasil interaksi individu dengan lingkungannya. Perubahan perilaku terhadap hasil belajar bersifat continiu, fungsional, positif, aktif, dan terarah. Proses perubahan tingkah laku dapat terjadi dalam berbagai kondisi berdasarkan penjelasan dari para ahli pendidikan dan psikologi. Adapun pembelajaran adalah proses interaksi peserta didik dengan pendidik, dengan bahan pelajaran, metode penyampaian, strategi pembelajaran, dan sumber belajar dalam suatu lingkungan belajar. Kemudian, keberhasilan dalam proses belajar dan pembelajaran dapat dilihat melalui tingkat keberhasilan dalam mencapai tujuan pendidikan. Dengan tercapainya tujuan pembelajaran, maka dapat dikatakan bahwa guru telah berhasil dalam mengajar. Dengan demikian, efektivitas sebuah proses belajar dan pembelajaran ditentukan oleh interaksi diantara komponenkomponen tersebut.

Dalam tulisan ini, penulis akan membahas mengenai pemahaman tentang hakikat belajar dan pembelajaran yang merupakan penjelasan tentang makna belajar dan makna pembelajaran, penjelasan tentang komponenkomponen pembelajaran, kemudian mengenai faktor-faktor yang mempengaruhi keberhasilan belajar dan pembelajaran.

\section{Hakikat Belajar dan Pembelajaran}

Dalam kegiatan belajar dan mengajar, peserta didik adalah subjek dan objek dari kegiatan pendidikan. Oleh karena itu, makna dari proses pengajaran adalah kegiatan belajar peserta didik dalam mencapai suatu tujuan pengajaran. Tujuan pengajaran akan dicapau apabila peserta didik berusaha secara aktif untuk mencapainya. Keaktifan anak didik tidak hanya dituntut dari segi fisik, tetapi juga dari segi kejiwaan. Apabila hanya dari segi fisik saja yang aktif dan mentalnya tidak aktif, maka tujuan dari pembelajaran belum tercapai. Hal ini sama saja dengan peserta didik tidak belajar, karena peserta didik tidak merasakan perubahan dalam dirinya. Belajar pada hakikatnya adalah suatu "perubahan" yang terjadi dalam diri seseorang setelah melakukan aktivitas belajar. ${ }^{1}$

${ }^{1}$ Syaiful Bahri Djamarah \& Aswan Zain, Strategi Belajar Mengajar (Jakarta: Rineka Cipta, 
1. Pengertian Belajar

Belajar menunjukkan aktivitas yang dilakukan oleh seseorang yang disadari atau disengaja. Aktivitas ini menunjuk pada keaktifan seseorang dalam melakukan aspek mental yang memungkinkan terjadinya perubahan pada dirinya. Dengan demikian, dapat dipahami juga bahwa suatu kegiatan belajar dikatakan baik apabila intensitas keaktifan jasmani maupun mental seseorang semakin tinggi. Sebaliknya meskipun seseorang dikatakan belajar, namun jika keaktifan jasmaniah dan mentalnya rendah berarti kegiatan belajar tersebut tidak secara nyata memahami bahwa dirinya melakukan kegiatan belajar. ${ }^{2}$

Kegiatan belajar juga dimaknai sebagai interaksi individu dengan lingkungannya. Lingkungan dalam hal ini adalah obyek-obyek lain yang memungkinkan individu memperoleh pengalaman-pengalaman atau pengetahuan, baik pengalaman atau pengetahuan baru maupun sesuatu yang pernah diperoleh atau ditemukan sebelumnya tetapi menimbulkan perhatian kembali bagi individu tersebut sehingga memungkinkan terjadinya interaksi. ${ }^{3}$

Tokoh psikologi belajar memiliki persepsi dan penekanan tersendiri tentang hakikat belajar dan proses ke arah perubahan sebagai hasil belajar. Berikut ini adalah beberapa kelompok teori yang memberikan pandangan khusus tentang belajar:

a. Behaviorisme, teori ini meyakini bahwa manusia sangat dipengaruhi oleh kejadian-kejadian di dalam lingkungannya yang memberikan pengalaman tertentu kepadanya. Behaviorisme menekankan pada apa yang dilihat, yaitu tingkah laku, dan kurang memperhatikan apa yang terjadi di dalam pikiran karena tidak dapat dilihat.

b. Kognitivisme, merupakan salah satu teori belajar yang dalam berbagai pembahasan juga sering disebut model kognitif. Menurut teori belajar ini tingkah laku seseorang ditentukan oleh persepsi atau pemahamannya tentang situasi yang berhubungan dengan tujuan. Oleh karena itu, teori ini memandang bahwa belajar itu sebagai perubahan persepsi dan pemahaman.

\footnotetext{
${ }^{2}$ Ainurrahman, Belajar dan Pembelajaran (Bandung: Alfabeta, 2013), hlm. 36.

${ }^{3}$ Ainurrahman, Belajar dan...., hlm. 36.
} 
FITRAH Jurnal Kajian Ilmu-ilmu Keislaman

Vol. 03 No. 2 Desember 2017

c. Teori Belajar Psikologi Sosial, menurut teori ini proses belajar bukanlah proses yang terjadi dalam keadaan menyendiri, akan tetapi harus melalui interaksi.

d. Teori Belajar Gagne, yaitu teori belajar yang merupakan perpaduan antara behaviorisme dan kognitivisme. Belajar merupakan sesuatu yang terjadi secara alamiah, akan tetapi hanya terjadi dengan kondisi tertantu. Yaitu kondisi internal yang merupakan kesiapan peserta didik dan sesuatu yang telah dipelajari, kemudian kondisi eksternal yang merupakan situasi belajar yang secara sengaja diatur oleh pendidik dengan tujuan memperlancar proses belajar. ${ }^{4}$

e. Teori Fitrah, pada dasarnya peserta didik lahir telah membawa bakat dan potensi-potensi yang cenderung kepada kebaikan dan kebenaran. Potensi-potensi tersebut pada hakikatnya yang akan dapat berkembang dalam diri seorang anak. ${ }^{5}$ Artinya adalah, teori fitrah dalam pendidikan Islam memandang seorang anak akan dapat mengembangkan potensipotensi baik yang telah dibawanya sejak lahir melalui pendidikan/ belajar. Dalam Alquran Allah berfirman:

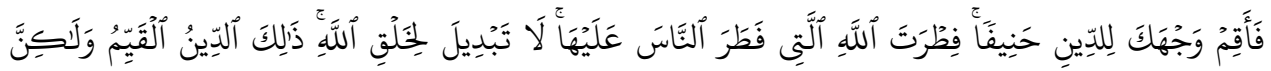

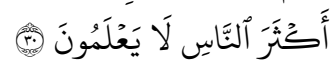

Artinya: Maka hadapkanlah wajahmu dengan lurus kepada agama Allah, tetaplah atas fitrah Allah yang telaah menciptakan manusia menurut fitrah itu, tidak ada perubahan pada fitrah Allah, itulah agama yang lurus; tetapi kebanyakan manusia tidak mengetahui.

Berdasarkan ayat di atas, dapat dikatakan bahwa tujuan agama diturunkan Allah kepada manusia adalah agar dapat mengarungi hidup dan penghidupannya di bumi ini sesuai dengan fitrah aslinya. ${ }^{6}$ Implikasi paedagogisnya adalah bahwa pendidikan mengemban tugas untuk mengupayakan agar kecenderungan-kecenderungan religious, intelegensi, sosio-kultural dan pemenuhan kebutuhan biologisnya benar-

${ }^{4}$ Ainurrahman, Belajar dan...., 39-47.

${ }^{5}$ Muhammad Darwis Dasopang, Jurnal Pendidikan: Perspektif Strategi Pembelajaran Akhlak Mulia Membangun Transformasi Sosial Siswa Smp Studi Multidisipliner Volume 1 Edisi 12014 M/1435 hlm 34 .

${ }^{6}$ Dja'far Siddik, Konsep Dasar Ilmu Pendidikan Islam (Citapustaka Media: 2006), hlm. 66. 
benar terarah sesuai dengan tujuan penciptaanya, sehingga senantiasa relevan dengan fitrah aslinya yang cinta pada kebaikan dan kebenaran. ${ }^{7}$

Dari uraian di atas, terkait dengan teori behaviorisme, kognitivisme, teori belajar psiko sosial, teori gagne serta yang terakhir adalah teori fitrah yang sesuai dengan pendidikan Islam, maka penulis menyimpulkan bahwa belajar adalah proses perubahan tingkah laku dan perubahan pemahaman, yang pada mulanya seorang anak tidak dibekali dengan potensi fitrah, kemudian dengan terjadinya proses belajar maka seorang anak beubah tingkah laku dan pemahamannya semakin betambah.

2. Pengertian Pembelajaran

Pembelajaran pada hakikatnya adalah suatu proses, yaitu proses mengatur, mengorganisasi lingkungan yang ada di sekitar peserta didik sehingga dapat menumbuhkan dan mendorong peserta didik melakukan proses belajar. Pembelajaran juga dikatakan sebagai proses memberikan bimbingan atau bantuan kepada peserta didik dalam melakukan proses belajar. Peran dari guru sebagai pembimbing bertolak dari banyaknya peserta didik yang bermasalah. Dalam belajar tentunya banyak perbedaan, seperti adanya peserta didik yang mampu mencerna materi pelajaran, ada pula peserta didik yang lambah dalam mencerna materi pelajaran. Kedua perbedaan inilah yang menyebabkan guru mampu mengatur strategi dalam pembelajaran yang sesuai dengan keadaan setiap peserta didik. Oleh karena itu, jika hakikat belajar adalah "perubahan", maka hakikat pembelajaran adalah "pengaturan". ${ }^{8}$

Menurut Undang-undang Republik Indonesia Nomor 20 tahun 2003 tantang Sistem Pendidikan Nasional, bahwa pembelajaran adalah proses interaksi pendidik dengan peserta didik dan sumber belajar yang berlangsung dalam suatu lingkungan belajar. 9 Secara Nasional, pembelajaran dipandang sebagai suatu proses interaksi yang melibatkan

${ }^{7}$ Dja'far Siddik, Konsep Dasar ....hlm. 67.

${ }^{8}$ Bahri Djamarah, Strategi Belajar........., hlm. 39.

${ }^{9}$ Republik Indonesia, Undang-undang Republik Indonesia Nomor 20 tahun 2003 tantang Sistem Pendidikan Nasional, hlm. 6. 
FITRAH Jurnal Kajian Ilmu-ilmu Keislaman

Vol. 03 No. 2 Desember 2017

komponen-komponen utama, yaitu peserta didik, pendidik, dan sumber belajar yang berlangsung dalam suatu lingkungan belajar, maka yang dikatakan dengan proses pembelajaran adalah suatu system yang melibatkan satu kesatuan komponen yang saling berkaitan dan saling berinteraksi untuk mencapai suatu hasil yang diharapkan secara optimal sesuai dengan tujuan yang telah ditetapkan.

Proses pembelajaran ditandai dengan adanya interaksi edukatif yang terjadi, yaitu interaksi yang sadar akan tujuan. Interaksi ini berakar dari pihak pendidik (guru) dan kegiatan belajar secara paedagogis pada diri peserta didik, berproses secara sistematis melalui tahap rancangan, pelaksanaan, dan evaluasi. Pembelajaran tidak terjadi seketika, melainkan berproses melalui tahapan-tahapan tertentu. Dalam pembelajaran, pendidik menfasilitasi peserta didik agar dapat belajar dengan baik. Dengan adanya interaksi tersebut maka akan menghasilkan proses pembelajaran yang efektif sebagaimana yang telah diharapkan. ${ }^{10}$

Menurut Trianto, pembelajaran adalah aspek kegiatan yang kompleks dan tidak dapat dijelaskan sepenuhnya. Secara sederhana, pembelajaran dapat diartikan sebagai produk interaksi berkelanjtan antara pengembangan dan pengalaman hidup. Pada hakikatnya, Trianto mengungkapkan bahwa pembelajaran merupakan usaha sadar dari seorang guru untuk membelajarkan peserta didiknya (mengarahkan interaksi peserta didik dengan sumber belajar lain) dengan maksud agar tujuannya dapat tercapai. Dari uraiannya tersebut, maka terlihat jelas bahwa pembelajaran itu adalah interaksi dua arah dari pendidik dan peserta didik, diantara keduanya terjadi komunikasi yang terarah menuju kepada target yang telah ditetapkan. ${ }^{11}$

Pola pembelajaran yang terjadi saat ini seringkali masih bersifat transmisif, yaitu siswa secara pasif menyerap struktur pengetahuan yang diberikan guru atau yang ada pada buku pelajaran saja. Adapun menurut Hudojo, menyatakan bahwa system pembelajaran dalam pandangan konstruktivis memberikan perbedaan yang nyata. Ciri-cirinya adalah: (a) siswa terlibat aktif dalam belajarnya. Siswa belajar materi secara bermakna

\footnotetext{
${ }_{10}$ Muh. Sain Hanafy, Jurnal Pendidikan: Konsep Belajar dan Pembelajaran, Lentera Pendidikan, Vol. 17 No. 1 Juni 2014: 66-79, hlm. 74.

11 Trianto, Mendesain Model Pembelajaran Inovatif- Progresif (Jakarta: Kencana, 2009), hlm. 19.
} 
dengan bekerja dan berpikir, dan (b) informasi baru harus dikaitkan dengan informasi sebelumnya sehinya menyatu dengan pengetahuan yang dimiliki oleh siswa. ${ }^{12}$

Jadi, dapat disimpulkan bahwa kegiatan pembelajaran ini dilakukan oleh dua orang pelaku, yaitu guru dan siswa. Perilaku guru adalah mengajar dan perilaku siswa adalah belajar. Perilaku mengajar dan perilaku belajar tersebut tidak terlepas dari bahan pelajaran. Dengan demikian, pembelajaran pada dasarnya adalah kegiatan terencana yang mengkondisikan atau merangsang seseorang agar dapat belajar dengan baik, sehingga kegiatan pembelajaran ini bermuara pada dua kegiatan pokok, yaitu bagaimana orang melakukan tindakan perubahan tingkah laku melalui kegiatan belajar dan bagaimana orang melakukan tindakan penyempaian ilmu pengetahuan melalui kegiatan mengajar. Oleh karena itu, makna pembelajaran merupakan tindakan eksternal dari belajar, sedangkan belajar adalah tindakan internal dari pembelajaran.

Dari uraian diatas mengenai belajar dan pembelajaran, maka penulis dapat memberikan ilustrasi mengenai konsep belajar dan pembelajaran, berikut ini adalah contoh ilustrasi:

Pak Ahmad adalah seorang guru di SMP Negeri 1. Ia juga mengajar Pendidikan Agama Islam. Pada minggu pertama tahun ajaran 20142015 ia masuk ke kelasnya. Ia mengemukakan pesan berikut: “anakanak, sekarang kalian kelas tiga. Ingat, pesan Bapak saat kelas satu yang lalu, siswa SMP belajar untuk mempersiapkan pelajaran ke SMA, ke sekolah kejuruan, atau mau bekerja. Sekarang kita memasuki semester lima, pada semester ke enam aka nada evaluasi belajar tahap akhir Nasional/ UN. Kalian semua hanya punya waktu sepuluh bulan lagi. Maka aturlah jadwal belajar kalian di rumah!" ajak Pak Ahmad dipatuhi siswa tersebut.

Annisa adalah siswa kelas tiga SMA. Ia anak yang rajin dan pandai. Sejak kelas satu SMA ia membuat jadwal belajar sendiri dirumah. Ia memiliki kelompok belajar juga.

Dari kedua ilustrasi di atas merupakan dampak dari belajar dan pembelajaran. Pak Ahmad memberikan informasi untuk membuat jadwal

12 Trianto, Mendesain Model....., hlm. 19. 
FITRAH Jurnal Kajian Ilmu-ilmu Keislaman

Vol. 03 No. 2 Desember 2017

belajar, dan Annisa membuat jadwal belajar sendiri dirumah sehingga ia menjadi murid yang rajin dan pintar. ${ }^{13}$

\section{Komponen-komponen Pembelajaran}

Pembelajaran dapat dikatakan sebagai suatu sistem, karena pembelajaran merupakan suatu kegiatan yang memiliki tujuan, yaitu membelajarkan siswa. Sebagai suatu sistem, tentu saja kegiatan belajar mengajar mengandung komponen. Proses pembelajaran merupakan serangkaian kegiatan yang melibatkan berbagai komponen yang satu sama lain saling berinteraksi, dimana guru harus memanfaatkan komponen tersebut dalam proses kegiatan untuk mencapai tujuan yang ingin direncanakan. ${ }^{14}$

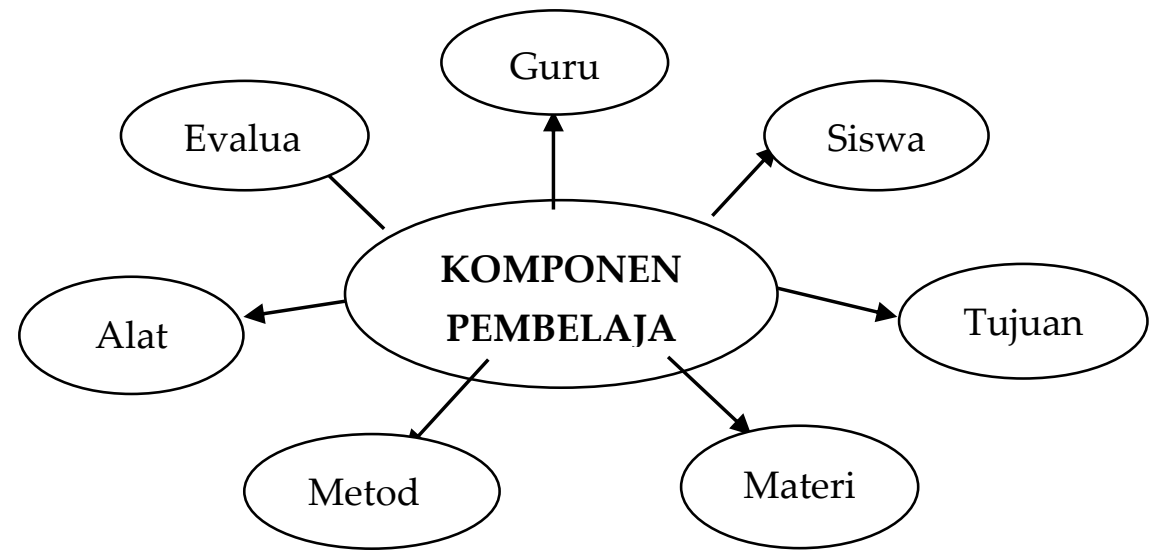

Gambar 1: Komponen Pembelajaran

Berikut ini adalah uraian dari komponen-komponen dalam pembelajaran:

1. Guru dan Siswa

Di dalam UU. RI No. 20 Tahun 2003 tentang sistem pendidikan Nasional, Bab IV Pasal 29 ayat 1 disebutkan bahwa pendidik merupakan tenaga professional yang bertugas merencanakan dan melaksanakan proses pembelajaran, memiliki hasil pembelajaran, melakukan bimbingan dan pelatihan serta melakukan penelitian dan pengabdian kepada masyarakat, terutama pada pendidik di Perguruan Tinggi. ${ }^{15}$

${ }^{13}$ Dimyati \& Mudjiono, Belajar dan Pembelajaran (Jakarta: Rineka Cipta, 2009) , hlm. 1.

${ }^{14}$ http://digilib.uinsby.ac.id/9620/5/Bab\%202.pdf, diakses pada: Kamis, 01/03/2018, Pukul: 14:38.

${ }^{15}$ Republik Indonesia, Undang-undang,....... hlm. 20. 
Guru adalah pelaku utama yang merencanakan, mengarahkan, dan melaksanakan kegiatan pembelajaran yang terdapat dalam upaya memberikan sejumlah ilmu pengetahuan kepada peserta didik di sekolah. Seorang guru haruslah memiliki kemampuan dalam mengajar, membimbing dan membina peserta didiknya dalam kegiatan pembelajaran. ${ }^{16}$

Berdasarkan keputusan Menpan No. 26/ MENPAN/ 1989, Tanggal 2 Mei 1989 dijelaskan, bahwa guru terlibat langsung dalam proses pendidikan. Oleh karena itu guru memegang peranan yang sangat menentukan bagi tujuan pendidikan. Guru haruslah meningkatkan kemampuan profesinya agar dapat melaksanakan tugas dengan baik. Pada kenyataan di lapangan, banyak dijumpai masalah berikut:

a. Penampilan (performance) guru di depan kelas dalam KBM belum memuaskan, padahal kualifikasi keguruannya beragam.

b. Kemajuan dan perkembangan ilmu pengetahuan dan tekhnologi (IPTEK) mulai menuntut adanya penyesuaian dari guru untuk mengembangkan pendidikan di sekolah. ${ }^{17}$

Dari kenyataan di lapangan tersebut, dapat dikatakan bahwa seorang guru merupakan komponen yang sangat menentukan dalam pelaksanaan strategi pembelajaran. Strategi pembelajaran tidak dapat diaplikasikan tanpa adanya guru. Keberhasilan suatu penerapan strategi pembelajaran sangat tergantung dengan guru dalam menggunakan metode, teknik dan taktik pembelajaran. Seorang guru yang memberikan materi pelajaran dengan hanya sebatas menyampaikan materi pelajaran akan berdeda dengan seorang guru yang menganggap mengajar adalah proses pemberian bantuan kepada peserta didik. ${ }^{18}$

Sama halnya dengan guru, faktor-faktor yang dapat mempengaruhi proses pembelajaran dilihat dari aspek siswa yang memiliki latar belakang berbeda-beda. Terdapat siswa yang berkemampuan tinggi, sedang dan rendah. Perbedaan tersebut tentunya memerlukan perlakuan yang berbeda. Sikap dan penampilan siswa di dalam kelas juga merupakan aspek lain yang

${ }^{16}$ Abudin Nata, Perspektif Islam tentang Strategi Pembelajaran (Jakarta: Kencana, 2009), hlm. 315.

17 Trianto, Mendesain Model......., hlm. 249-250.

18 Wina Sanjaya, Strategi Pembelajaran Berorientasi Standar Proses Pendidikan (Jakarta: Kencana, 2010), hlm. 52. 
FITRAH Jurnal Kajian Ilmu-ilmu Keislaman

Vol. 03 No. 2 Desember 2017

mempengaruhi proses pembelajaran. ${ }^{19}$ Oleh sebab itu, peran siswa juga sangat mempengaruhi guru dalam proses pembelajaran, begitupun sebaliknya.

Dja'far Siddik mengungkapkan persoalan yang sering terjadi antara guru dengan siswa adalah konsep pendidikan yang memposisikan para guru atau pedidik yang dikelompokkan pada proses pembelajaran yang terpusat pada guru (teacher centered) atau terpusat pada siswa (student centered). Dalam pendidikan Islam, istilah fitrah manusia terdapat pada seluruh aspek rohaniah dan jasmaniah manusia, baik berupa sifat dasar moral atau bakat keterampilan yang dimiliki. Menurut pandangan Islam, kecenderungan dan bakat yang dimiliki siswa akan dapat dilakukan apabila siswa tersebut memperoleh pengalaman dan pengetahuan. Maka, tidak semua yang ingin diketahui oleh siswa dapat diperoleh dengan sendirinya tanpa bantuan guru. Siswa dan guru, masing-masing mempunyai kedaulatan yang sama dalam hal bekerja sama dalam proses pembelajaran. Konsep seperti inilah yang menjadikan hadirnya dua pilihan, terpusat pada guru (teacher centered) ataukah terpusat pada siswa (student centered). Jika dilihat dari posisi guru yang menjadi pelaku aktif, maka pastilah memberikan peluang bagi terlaksanakannya proses pembelajaran yang terpusat pada guru. Sebaliknya, jika dilihat dari posisi siswa yang juga pelaku aktif, maka dapat juga diberi peluang untuk melaksanakan proses pembelajaran yang terpusat pada siswa. ${ }^{20}$

2. Tujuan Pembelajaran

Tujuan pembelajaran adalah faktor yang sangat penting dalam proses pembelajaran. Dengan adanya tujuan, maka guru memiliki pedoman dan sasaraan yang akan dicapai dalam kegiatan mengajar. Apabila tujuan pembelajaran sudah jelas dan tegas, maka langkah dan kegiatan pembelajaran akan lebih terarah. Tujuan dalam pembelajaran yang telah dirumuskan hendaknya disesuaikan dengan ketersediaan waktu, sarana prasarana dan kesiapan peserta didik. Sehubungan dengan hal itu, maka seluruh kegiatan guru dan peserta didik harus diarahkan pada tercapainya tujuan yang telah diharapkan. $^{21}$

\footnotetext{
${ }^{19}$ Wina Sanjaya, Strategi Pembelajaran...., hlm. 54.

${ }^{20}$ Siddik, Ilmu Pendidikan...., hlm. 98-99.

${ }^{21}$ Nata, Pespektif Islam tentang........., hlm. 314.
} 
Tujuan merupakan komponen yang dapat mempengaruhi komponen pengajaran lainnya, seperti bahan pelajaran, kegiatan belajar mengajar, pemilihan metode, alat, sumber dan alat evaluasi. Oleh Karena itu, maka seorang guru tidak dapat mengabaikan masalah perumusan tujuan pembelajaran apabila hendak memprogramkan pengajarannya. ${ }^{22}$

Jika dilihat dari sisi ruang lingkupnya, tujuan pembelajaran dapat dibagi menjadi dua bagian, yaitu:

a. Tujuan yang dirumuskan secara spesifik oleh guru yang bertolak dari materi pelajaran yang akan disampaikan

b. Tujuan Pembelajaran Umum, yaitu tujuan pembelajaran yang sudah tercantum dalam garis-garis besar pedoman pengajaran yang dituangkan dalam rencana pengajaran yang disiapkan oleh guru. Tujuan khusus yang dirumuskan oleh seorang guru harus memenuhi syarat-syarat, yaitu:

1) Secara spesifik menyatakan perilaku yang akan dicapai

2) Membatasi dalam keadaan mana pengetahuan perilaku diharapkan dapat terjadi (kondisi perubahan perilaku)

3) Secara spesifik menyatakan criteria perubahan perilaku dalam arti menggambarkan stanndar minimal perilaku yang dapat diterima sebagai hasil yang dicapai. ${ }^{23}$

3. Materi Pembelajaran

Materi pembelajaran adalah substansi yang akan disampaikan dalam proses belajar mengajar. Tanpa adanya materi pembelajaran proses belajar mengajar tidak akan berjalan. Oleh karena itu, guru yang akan mengajar pasti memiliki dan menguasai materi pelajaran yang akan disampaikan kepada siswa. Materi pelajaran merupakan satu sumber belajar bagi siswa. Materi yang disebut sebagai sumber belajar ini adalah sesuatu yang membawa pesan untuk tujuan pembelajaran. Suharsimi Arikunto memandang bahwa materi pelajaran merupakan unsure inti yang ada di dalam kegiatan belajar mengajar, karena bahan pelajaran itulah yang diupayakan untuk dikuasai oleh siswa. Maka, seorang guru ataupun pengembang kurikulum seharusnya tidak boleh lupa harus memikirkan sejauh mana bahan-bahan yang topiknya

\footnotetext{
${ }^{22}$ Bahri Djamarah, Strategi Belajar......hlm. 42.

${ }^{23}$ Nata, Pespektif Islam tentang........, hlm. 315.
} 
FITRAH Jurnal Kajian Ilmu-ilmu Keislaman

Vol. 03 No. 2 Desember 2017

tertera yang berhubungan dengan kebutuhan siswa pada usia tertentu dan dalam lingkungan tertentu pula. ${ }^{24}$

Pada umumnya, aktivitas siswa akan berkurang jika materi pelajaran yang diberikan oleh guru tidak menarik perhatiannya disebabkan cara mengajar yang mengabaikan prinsip-prinsip mengajar. Sering sekali guru merasa telah menguasai materi pelajaran dengan menggunakan bahasa yang tidak sesuai dengan perkembangan bahkan jiwa siswa, dengan begitu maka guru akan mengalami kegagalan dalam menyampaikan materi dan sebaliknya pula, siswa akan mengalami kegagalan dalam menerima pelajaran. ${ }^{25}$

Materi pembelajaran juga perlu dipilih dengan tepat agar dapat membantu siswa untuk mencapai standar kompetensi dan kompetensi dasar. Pada hakikatnya, jenis materi pembelajaran memerlukan strategi, media dan cara evaluasi yang berbeda-beda. Ruang lingkup dan kedalaman materi pembelajaran sangat perlu diperhatikan agar sesuai dengan tingkat kompetensinya. Urutan materi pembelajaran perlu diperhatikan agar pembelajaran menjadi terarah. Adapun cara mengajarkan/ menyampaikan materi pembelajaran juga perlu dipilih secara tepat agar tidak salah mengajarkannya.

Karena itu, lebih baik menyampaikan materi pelajaran sesuai dengan perkembangan siswa. Dengan demikian, materi pembelajaran merupakan komponen yang tidak bias diabaikan dalam pembelajaran, sebab materi adalah inti dari proses belajar mengajar yang disampaikan kepada siswa. ${ }^{26}$

\section{Metode Pembelajaran}

Menurut J.R David dalam Teaching Strategies for College Class Room yang dikutip oleh Abdul Majid, mengatakan bahwa pengertian metode adalah cara untuk mencapai sesuatu. Untuk melaksanakan suatu strategi digunakan seperangkan metode pengajaran tertentu. Dalam pengertian demikian ini, maka metode pembelajaran menjadi ssalah satu unsure dalam strategi belajar mengajar. Metode pembelajaran digunakan oleh guru untuk menciptakan

${ }^{24}$ Bahri Djamarah, Strategi Belajar......, hlm. 44.

${ }^{25}$ Bahri Djamarah, Strategi Belajar......, hlm. 44.

${ }^{26}$ Wina Sanjaya, Strategi Pembelajaran Berorientasi Standar Proses Pendidikan (Jakarta: Kencana, 2010), hlm. 60. 
lingkungan belajar dan mengkhususkan aktivitas guru dan siswa terlibat selama proses pembelajaran. ${ }^{27}$

Metode pembelajaran didefinisikan sebagai cara yang digunakan guru dalam menjalankan fungsinya dan merupakan alat untuk mencapai tujuan pembelajaran. Metode pembelajaran dengan tekhnik adalah dua hal yang berbeda. Metode pembelajaran lebih bersifat procedural, yaitu berisi tahapantahapan tertentu, sedangkan tekhnik adalah cara yang digunakan dan bersifat implementatif. Dengan kata lain, metode dapat sama, akan tetapi tekhniknya berbeda. ${ }^{28}$

Metode pembelajaran suatu cara yang digunakan dalam mencapai tujuan yang telah ditetapkan. Dalam kegiatan belajar mengajar, metode sangat diperlukan oleh guru, penggunaan metode dapat dilakukan secara bervariasi sesuai dengan tujuan yang ingin dicapai. Penggunaan metode pembelajaran yang bervariasi akan memberikan suasana belajar yang menarik, dan tidak membosankan bagi peserta didik. Akan tetapi, bisa saja penggunaan metode yang bervariasi menjadikan kegiatan belajar tidak menguntungkan jika penggunaan metode variasinya tidak tepat. Oleh karena itulah, dalam menggunakan metode pembelajaran dibutuhkan kompetensi guru untuk memilih metode yang tepat. Adapun faktor-faktor yang dapat mempengaruhi penggunaan metode pembelajaran adalah sebagai berikut:

a. Tujuan yang bermacam-macam jenis dan fungsinya

b. Peserta didik yang berbagai macam tingkat usianya

c. Situasi yang berbagai macam keadaannya

d. Fasilitas yang berbagai macam kualitas dan kuantitasnya

e. Pribadi guru serta kemampuan profesionalnya yang berbeda-beda. ${ }^{29}$

Tabel-tabel dibawah ini akan menggambarkan kombinasi metode dalam pembelajaran: ${ }^{30}$

a. Ceramah, Tanya Jawab dan Tugas

\begin{tabular}{|l|c|c|}
\hline No. & Langkah & Jenis Kegiatan Belajar Mengajar \\
\hline 1 & Persiapan & 1. Menciptakan kondisi belajar siswa \\
\hline
\end{tabular}

27 Abdul Majid, Belajar dan Pembelajaran Pendidikan Agama Islam (Bandung: Remaja Rosdakarya, 2014), hlm. 132.

${ }^{28}$ Hamzah B. Uno \& Nurdin Mohamad, Belajar dengan Pendekatan PAILKEM (Jakarta: Bumi Aksara, 2011), hlm. 7.

${ }^{29}$ Bahri Djamarah, Strategi Belajar.......hlm. 46.

${ }^{30}$ Bahri Djamarah, Strategi Belajar...., hlm. 98-104. 
FITRAH Jurnal Kajian Ilmu-ilmu Keislaman

Vol. 03 No. 2 Desember 2017

\begin{tabular}{|c|c|c|}
\hline 2 & Pelaksanaan & $\begin{array}{l}\text { 2. Penyajian, guru menyampaikan bahan pelajaran } \\
\text { (metode, ceramah) } \\
\text { 3. Asosiasi/ komparasi, artinya memberi kesempatan } \\
\text { pada siswa untuk menghubungkan dan } \\
\text { membandingkan materi ceramah yang telah } \\
\text { diterimanya melalui Tanya jawab } \\
\text { 4. Kesimpulan, memberikan tugas melalui hasil } \\
\text { ceramah (metode tugas) }\end{array}$ \\
\hline 3 & $\begin{array}{l}\text { Evaluasi/ } \\
\text { Tindak } \\
\text { Lanjut }\end{array}$ & $\begin{array}{l}\text { 5. Mengadakan penilaian terhadap pemahaman } \\
\text { siswa mengenai bahan yang telah diterimanya } \\
\text { melalui tes lisan dan tulisan atau tugas lain. }\end{array}$ \\
\hline
\end{tabular}

b. Ceramah, Diskusi, dan Tugas

\begin{tabular}{|c|c|c|}
\hline No. & Langkah & Jenis Kegiatan Belajar Mengajar \\
\hline 1 & Persiapan & $\begin{array}{l}\text { 1. Mempersiapkan kondisi belajar siswa } \\
\text { 2. Memberikan informasi/ penjelasan tentang } \\
\text { masalah tugas dalam diskusi (ceramah) } \\
\text { 3. Mempersiapkan sarana/prasarana untuk } \\
\text { melakukan diskusi (tempat, peserta, dan } \\
\text { waktu) }\end{array}$ \\
\hline 2 & Pelaksanaan & $\begin{array}{l}\text { 4. Siswa melakukan diskusi: } \\
\text { - Guru merangsang seluruh peserta } \\
\text { berpartisipasi dalam diskusi } \\
\text { - } \text { Memberikan kesempatan kepada siswa } \\
\text { untuk aktif } \\
\text { - Mencatat tanggapan/saran yang peting }\end{array}$ \\
\hline 3 & $\begin{array}{l}\text { Evaluasi/ } \\
\text { Tindak Lanjut }\end{array}$ & $\begin{array}{l}\text { 5. } \text { Memberikan tugas kepada siswa, untuk: } \\
\text { - } \quad \text { Membuat kesimpulan diskusi } \\
\text { - } \\
\text { - } \\
\text { Mencatat hasil diskusi } \\
\text { Menilai hasil diskusi }\end{array}$ \\
\hline
\end{tabular}

c. Ceramah, Demonstrasi dan Eksperimen

\begin{tabular}{|l|l|l|}
\hline No. & Langkah & \multicolumn{2}{|c|}{ Jenis Kegiatan Belajar Mengajar } \\
\hline 1 & Persiapan & 1. Mempersiapkan kondisi belajar siswa untuk \\
\hline
\end{tabular}




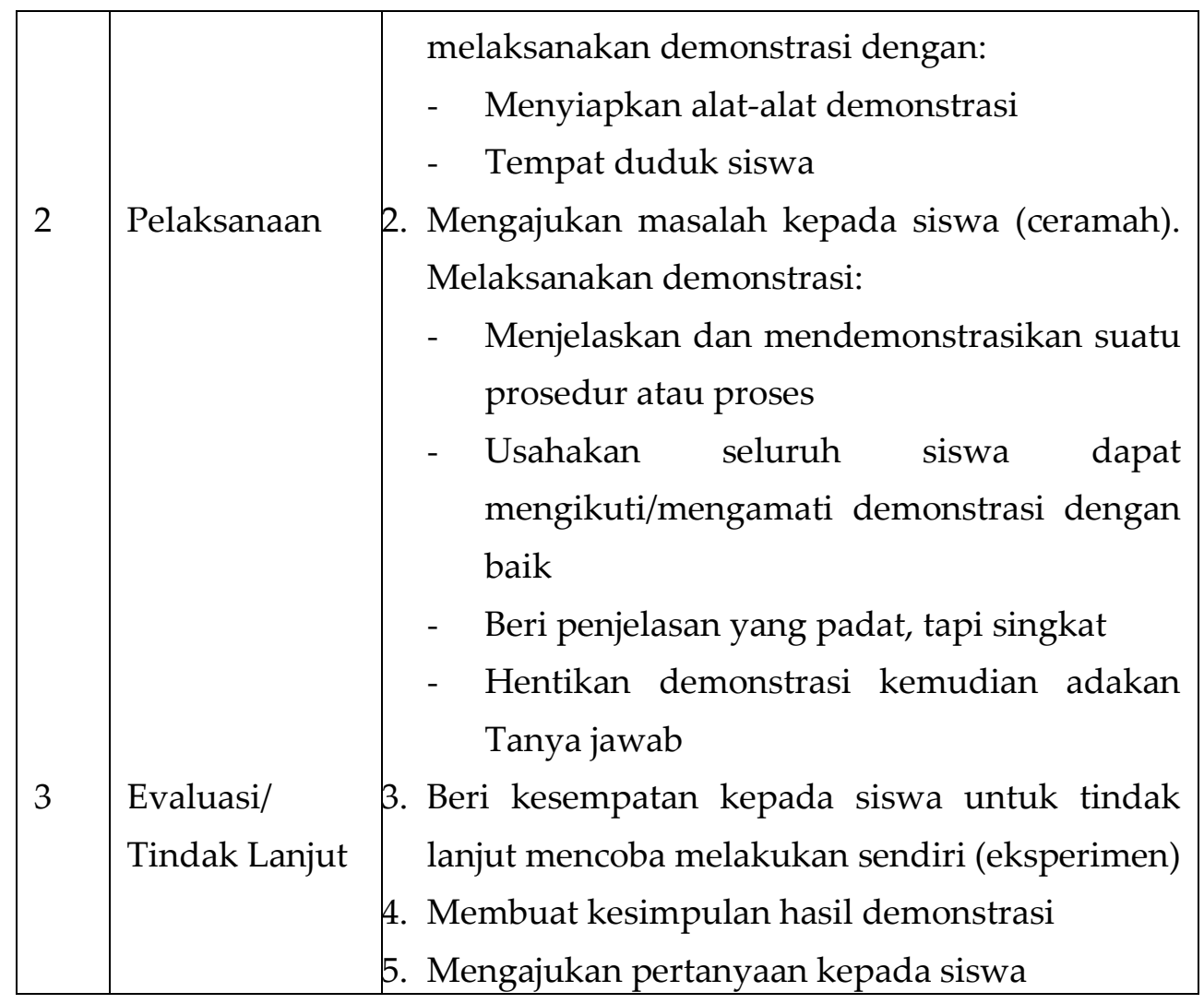

d. Ceramah, Sosiodrama, dan Diskusi

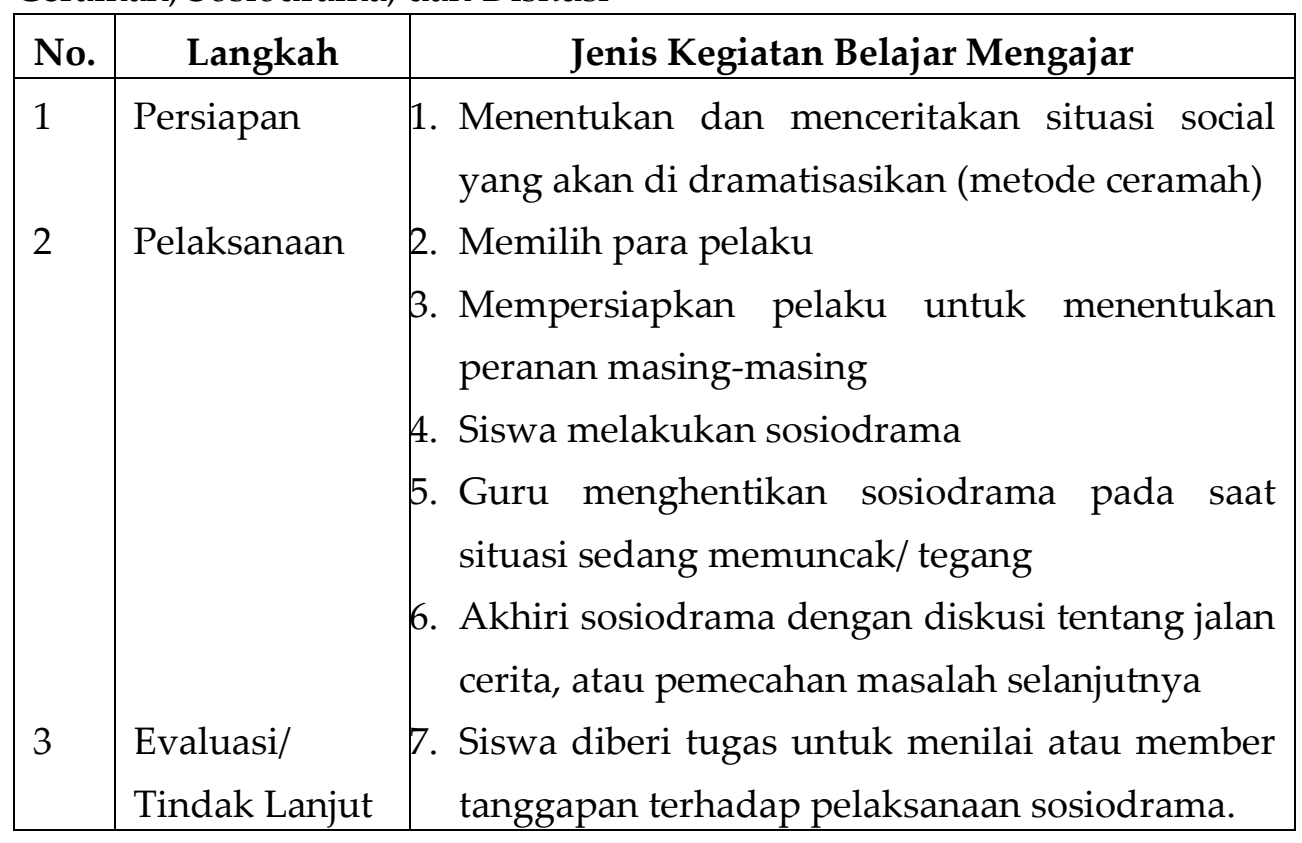

e. Ceramah, Problem Solving dan Tugas 
FITRAH Jurnal Kajian Ilmu-ilmu Keislaman

Vol. 03 No. 2 Desember 2017

\begin{tabular}{|c|c|c|}
\hline No. & Langkah & Jenis Kegiatan Belajar Mengajar \\
\hline 1 & Persiapan & 1. Menentukan dan menjelaskan masalah \\
\hline 2 & Pelaksanaan & $\begin{array}{l}\text { 2. Menyediakan alat/ buku-buku yang relevan } \\
\text { dengan masalah tersebut } \\
\text { 3. Siswa mengadakan identifikasi masalah } \\
\text { 4. Merumuskan hipotesis atau jawaban sementara } \\
\text { dalam memecahkan masalah tersebut } \\
\text { 5. Mengumpulkan data atau keterangan yang } \\
\text { relevan dengan masalah }\end{array}$ \\
\hline 3 & $\begin{array}{l}\text { Evaluasi/ } \\
\text { Tindak Lanjut }\end{array}$ & $\begin{array}{l}\text { 6. Menguji hipotesis (siswa memecahkan masalah } \\
\text { yang dihadapinya dengan data yang ada) } \\
\text { 7. Membuat kesimpulan pemecahan masalah }\end{array}$ \\
\hline
\end{tabular}

f. Ceramah, Demonstrasi dan Latihan

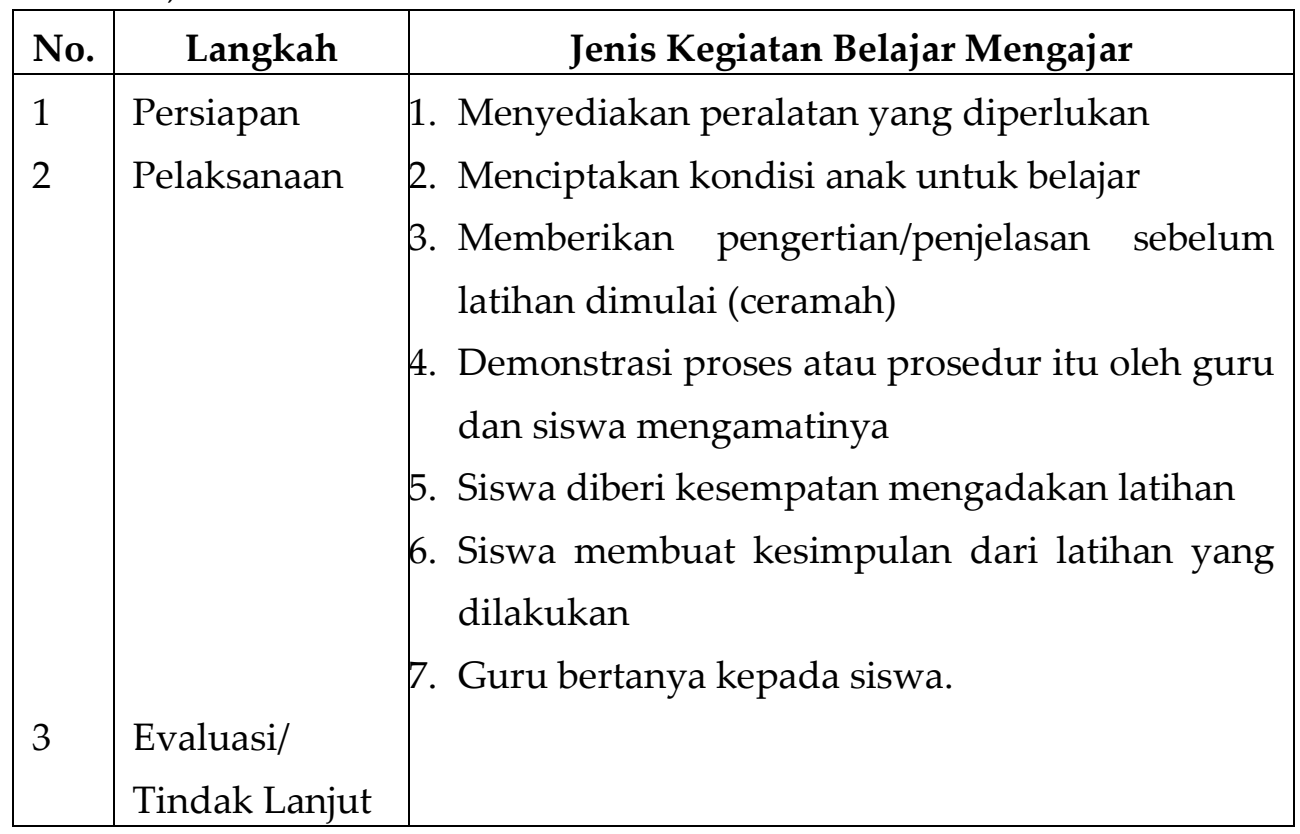

Dengan demikian, penggunaan metode dalam proses mengajar dapat dikombinasikan secara bervariasi, tujuannya agar memberikan suasana belajar yang menarik, dan tidak membosankan bagi peserta didik.

6. Alat Pembelajaran 
Alat pembelajaran adalah media yang berfungsi sebagai alat bantu untuk memperlancar penyelengaraan pembelajaran aga lebih efisien dan efektif dalam mencapai tujuan pembelajaran. Alat atau media pembelajaran dapat berupa orang, makhluk hidup, benda-benda, dan segala sesuatu yang dapat digunakan guru sebagai perantara untuk menyajikan bahan pelajaran. ${ }^{31}$

Pada dasarnya, setiap alat pembelajaran memiliki kelebihan dan kelemahan. Hal itu sejalan dengan fungsi dari alat tersebut dalam setiap penggunaannya. Oleh karena itu, dalam menggunakan alat pembelajaran, perlu mempertimbangkan beberapa hal berikut:

a. Alat pendidikan harus cocok atau sesuai dalam mencapai tujuan pembelajaran tertentu.

b. Pendidik memahami dengan baik peranan alat pembelajaran yang digunakan serta dapat memanfaatkannya secara baik sesuai dengan bahan/ materi pelajaran serta tujuan pembelajaran yang telah ditentukan.

c. Peserta didik dapat menerima dengan baik penggunaan alat pembelajaran sesuai dengan kondisi dan latar belakang usianya, dan bakat-bakatnya

d. Alat pembelajaran haruslah memberikan dampak atau hasil yang baik serta tidak menimbulkan dampak negative terhadap perkembangan akhlak agamanya, maupun terhadap perkembangan fisik dan psikologisnya. ${ }^{32}$

Menurut Roestiyah, mengatakan jenis alat-alat pembelajaran:

a. Manusia

b. Buku

c. Media massa (majalah, surat kabar, radio, tv, dan lain-lain)

d. Lingkungan

e. Alat pengajaran (buku pengajaran, peta, gambar, kaset, tape, papan tulis, kapur, spidol, dan sebagainya)

f. Museum (penyimpanan benda kuno). ${ }^{33}$

Penggunaan media dalam pembelajaran haruslah disesuaikan dengan kondisi yang sedang berlangsung. Media atau alat pembelajaran yang digunakan harus sesuai dengan materi yang diajarkan, dengan adanya media atau alat pembelajaran ini sudah seharusnya dapat memudahkan guru dalam

\footnotetext{
${ }^{31}$ Siddik, Ilmu Pendidikan......., hlm. 142.

32 Siddik, Ilmu Pendidikan......, hlm. 143.

${ }^{33}$ Bahri Djamarah, Strategi Belajar......hlm. 49.
} 
FITRAH Jurnal Kajian Ilmu-ilmu Keislaman

Vol. 03 No. 2 Desember 2017

menyampaikan pembelajaran sehingga tujuan dari materi yang disampaikan dapat dicapai oleh siswa.

7. Evaluasi

Evaluasi merupakan komponen terakhir dalam sistem pembelajaran. Evaluasi bukan saja berfungsi untuk melihat keberhasilan siswa dalam pembelajaran, akan tetapi juga berfungsi sebagai umpan balik guru atas kinerja yang telah dilakukannya dalam proses pembelajaran. Melalui evaluasi dapat diketahui kekurangan dalam pemanfaatan berbagai komponen dalam pembelajaran. ${ }^{34}$

Dja'far Siddik mengungkapkan bahwa fungsi evaluasi adalah:

a. Intensif untuk meningkatkan peserta didik belajar

b. Umpan balik bagi peserta didik

c. Umpan balik bagi pendidik

d. Informasi bagi orangtua/ wali

e. Informasi untuk lembaga. ${ }^{35}$

Dengan adanya evaluasi dalam pembelajaran, sehingga guru akan mengetahui sejauh mana siswa dapat memahami materi yang disampaikan. Apabila dalam proses pembelajaran tidak ada evaluasi, maka guru, siswa, orangtua/ wali siswa, serta lembaga tidak akan mengetahui hasil yang diperoleh dari pembelajaran. Oleh karena itu, evaluasi sangatlah penting dalam proses belajar mengajar.

\section{PENUTUP}

Dari uraian di atas dapat disimpulkan bahwa belajar dan pembelajaran merupakan dua aspek yang saling berhubungan. Kegiatan belajar dan pembelajaran adalah proses interaksi yang bersifat edukasi dalam rangka mencapai tujuan pendidikan. Belajar merupakan suatu sistem yang termuat

\footnotetext{
${ }^{34}$ Sanjaya, Stratei Pembelajaran Berorientasi....., hlm. 61.

${ }^{35}$ Siddik, Ilmu Pendidikan....... hlm. 160.
} 
dalam proses pembelajaran, dan pembelajaran terdiri dari beberapa komponen yang saling berinteraksi satu sama lain, yang terdiri dari: guru, siswa, tujuan, materi, media, metode, dan evaluasi.

Komponen-komponen pembelajaran adalah seluruh aspek yang saling membutuhkan. Pembelajaran tidak akan dapat terlaksana dengan baik tanpa adanya komponen pembelajaran, dan komponen pembelajaran memiliki hubungan yang erat satu sama lain tanpa dapat dipisahkan. Dengan demikian, seluruh komponen haruslah digunakan dalam proses pembelajaran. Apabila salah satu komponen tidak digunakan, maka pembelajaran tidak akan efektif. 
FITRAH Jurnal Kajian Ilmu-ilmu Keislaman

Vol. 03 No. 2 Desember 2017

\section{DAFTAR PUSTAKA}

Abdul Majid, Belajar dan Pembelajaran Pendidikan Agama Islam, Bandung: Remaja Rosdakarya, 2014.

Abudin Nata, Perspektif Islam tentang Strategi Pembelajaran, Jakarta: Kencana, 2009.

Aunurrahman, Belajar dan Pembelajaran, Bandung: Alfabeta, 2013.

Dja'far Siddik, Ilmu Pendidikan Islam, Bandung: Citapustaka Media, 2006.

Dimyati \& Mudjiono, Belajar dan Pembelajaran, Jakarta: Rineka Cipta, 2009.

Hamzah B. Uno \& Nurdin Mohamad, Belajar dengan Pendekatan PAILKEM, Jakarta: Bumi Aksara, 2011.

http://digilib.uinsby.ac.id/9620/5/Bab\%202.pdf, diakses pada: Kamis, 01/03/2018, Pukul: 14:38

Muh. Sain Hanafy, Jurnal Pendidikan: Konsep Belajar dan Pembelajaran, Lentera Pendidikan, Vol. 17 No. 1 Juni 2014: 66-79.

Muhammad Darwis Dasopang, Jurnal Pendidikan: Perspektif Strategi Pembelajaran Akhlak Mulia Membangun Transformasi Sosial Siswa Smp, Studi Multidisipliner Volume 1 Edisi 12014 M/1435.

Republik Indonesia, Undang-undang Republik Indonesia Nomor 20 tahun 2003 tantang Sistem Pendidikan Nasional.

Syaiful Bahri Djamarah \& Aswan Zain, Strategi Belajar Mengajar, Jakarta: Rineka Cipta, 2006.

Trianto, Mendesain Model Pembelajaran Inovatif- Progresif, Jakarta: Kencana, 2009.

Wina Sanjaya, Strategi Pembelajaran Berorientasi Standar Proses Pendidikan, Jakarta: Kencana, 2010. 